\title{
PERAN DAN TANGGUNG JAWAB PEJABAT PEMBUAT AKTA TANAH TERKAIT AKTA PEMBERIAN HAK TANGGUNGAN DALAM AKAD MUDHARABAH PADA BANK SYARIAH
}

\author{
Rina Nurhidayati \\ Program Magister Kenotariatan \\ Program Pascasarjana Fakultas Hukum \\ Universitas Islam Indonesia \\ Jl.Cik Di Tiro No. 1 Yogyakarta, Telp./Fax: (0274) 520661 \\ Email: rinanurhidayati84@gmail.com
}

\begin{abstract}
This study reviews the concept of binding guarantee of the rights to land in accordance with laws and regulations in Indonesia and Islamic law; as well as the roles and responsibilities associated with APHT PPAT in the contract of Mudharabah Islamic Bank. The method used in this research is normative. The results showed that APHT can not be used on the contract of Mudharabah and Islamic law has its own security institutions, namely Rahn. Roles and responsibilities of PPAT associated with APHT in the contract of Mudharabah Islamic Bank will be explained by Act No. 4 of 1996, Act No. 21 of 2008, Government Regulation No. 37 of 1998, as amended by Regulation No. 24 of 2016, PERKABAN No. 1 of 2006, as amended by PERKABAN No. 23 of 2009 and Theory of Accountability.
\end{abstract}

Keywords: Liability, Land Deed Official, Granting of Warranty Right Deed, Mudharabah Contract and Islamic Bank.

\begin{abstract}
Abstrak
Penelitian ini mengkaji tentang konsep pengikatan jaminan terhadap hak atas tanah menurut peraturan perundang-undangan di Indonesia dan Hukum Islam; serta peran dan tanggung jawab PPAT terkait dengan APHT dalam akad Mudharabah pada Bank Syariah. Metode yang digunakan dalam penelitian ini adalah yuridis normatif. Hasil penelitian menunjukkan bahwa APHT tidak dapat digunakan pada akad Mudharabah dan hukum Islam memiliki lembaga jaminan tersendiri yaitu Rahn. Peran dan tanggung jawab PPAT terkait dengan APHT dalam akad Mudharabah pada Bank Syariah akan dijelaskan berdasarkan Undang-Undang Nomor 4 tahun 1996, Undang-Undang Nomor 21 tahun 2008, PP Nomor 37 tahun 1998 yang telah diubah dengan PP Nomor 24 Tahun 2016, PERKABAN Nomor 1 tahun 2006 yang telah diubah dengan PERKABAN Nomor 23 Tahun 2009 dan Teori Pertanggungjawaban.
\end{abstract}

Kata Kunci : Tanggung Jawab, Pejabat Pembuat Akta Tanah, Akta Pemberian Tanggungan, Akad Mudharabah dan Bank Syariah. 


\section{Pendahuluan}

Perbankan syariah berkembang begitu pesat termasuk di Eropa, Australia dan Amerika. Berkembangnya bank-bank syariah di negara-negara Islam berpengaruh pula ke Indonesia. Perkembangannya pada era reformasi ditandai dengan disetujuinya UndangUndang (UU) Nomor 10 tahun 1998 tentang Perubahan atas UU Nomor 7 Tahun 1992 tentang Perbankan. Dalam Undang-Undang tersebut telah diatur dengan rinci dasar hukum serta jenis-jenis usaha yang dapat diimplementasikan oleh bank syariah yang juga memberikan arahan bagi bank konvensional untuk membuka cabang syariah atau bahkan mengonversi diri secara total menjadi bank syariah.

Faktor yang paling menentukan dalam perkembangan perbankan syariah tersebut adalah banyaknya jumlah nasabah, khususnya nasabah pembiayaan yang dapat dilihat pada data Statistik Perbankan Syariah. Hal itu sangat diharapkan pada perbankan syariah terutama pembiayaan berupa transaksi bagi hasil, yang secara syariah, prinsipnya berdasarkan kaidah al-mudharabah karena prinsip bagi hasil (profit sharing) merupakan karakteristik umum dan landasan dasar bagi operasional bank syariah secara keseluruhan. ${ }^{1}$

Akad atau kontrak mudharabah adalah kontrak menanggung untung dan rugi antara pemilik dana dan nasabah. Oleh karena itu, landasan moralitas yang kuat sangat dibutuhkan dalam pola kerjasama pembiayaan mudharabah ini. Bahkan menurut Muhammad, prinsipprinsip agama dapat digunakan sebagai pengendali diri agar seseorang tidak berbuat bohong (hazard) tetapi mereka dapat jujur dalam menyampaikan hasil usaha yang diperoleh. ${ }^{2}$

Tetapi, kompleksitas masyarakat saat ini membuat rumit hubungan antar individu manusia dengan landasan moralitas yang kuat tadi sehingga bukan merupakan suatu perkara yang mudah untuk menciptakan kelancaran pembiayaan mudharabah antara bank syariah dan nasabahnya. Karena itulah, pihak perbankan syariah membutuhkan suatu bentuk perlindungan hukum agar dapat menerapkan prinsip bagi hasil dalam pembiayaan mudharabah secara aman dan saling menguntungkan bagi kedua belah pihak.

Perlindungan Hukum merupakan unsur yang harus ada dalam suatu negara. Perlindungan Hukum akan menjadi hak bagi warga negara namun di sisi lain perlindungan hukum menjadi kewajiban bagi negara. Perlindungan hukum merupakan suatu perlindungan

\footnotetext{
${ }^{1}$ Muhammad Syafi'i Antonio, Bank Syariah Dari Teori Ke Praktik, Cetakan Pertama, Gema Insani Press bekerjasama dengan Tazkia Cendikia, Jakarta, 2001, hlm. 137.

${ }^{2}$ Muhammad, Manajemen Bank Syariah, Edisi Revisi Yogyakarta, UPP AMP YKPN, 2005, hlm. 371.
} 
yang diberikan terhadap subyek hukum (dari tindakan sewenang-wenang seseorang) dalam bentuk perangkat hukum baik yang bersifat preventif maupun yang bersifat represif, baik yang tertulis maupun tidak tertulis. ${ }^{3}$

Salah satu bentuk perlindungan hukum kepada pihak perbankan syariah dalam mengurangi risiko pembiayaan mudharabah yaitu diperbolehkannya pihak bank meminta jaminan kepada pihak nasabah yang hendak mengajukan pembiayaan. Sebagaimana diatur dalam UU Nomor 21 Tahun 2008 tentang Perbankan Syariah, Fatwa Dewan Syari'ah Nasional Majelis Ulama Indonesia (Fatwa DSN-MUI) Nomor 07/DSN-MUI/IV/2000 tentang Pembiayaan Mudharabah (Qiradh), Fatwa DSN-MUI Nomor 74/DSN-MUI/I/2009 tentang Penjaminan Syariah dan Peraturan Bank Indonesia (PBI) Nomor 7/46/PBI/2005 tentang Akad Penghimpunan dan Penyaluran Dana bagi Bank yang Melaksanakan Kegiatan Usaha Berdasarkan Prinsip Syariah.

Meskipun praktik pengenaan jaminan untuk pembiayaan mudharabah di Indonesia sah adanya menurut beberapa peraturan tersebut di atas namun dalam perkembangan pemikiran figh muamalah, ada perbedaan pandangan para ulama Islam mengenai keberadaan jaminan pada bank syariah. Kepercayaan merupakan prinsip terpenting dalam transaksi pembiayaan mudharabah. Prinsip inilah yang membedakan pembiayaan yang menggunakan akad mudharabah dengan akad-akad lainnya. ${ }^{4}$ Atas dasar prinsip tersebut, pihak pemilik modal (shahibul maal) tidak dapat menuntut jaminan apapun dari mudharib untuk mengembalikan modal atau modal dengan keuntungan. Jika pihak shahibul maal mensyaratkan pemberian jaminan dari nasabah pengelola (mudharib) dan menyatakan hal ini dalam syarat akad maka akad mudharabah tersebut menjadi tidak sah atau batal. Hal demikian menurut Imam Malik dan Syafi' 'i. ${ }^{5}$

Meskipun demikian, dalam kenyataannya, bank-bank Islam umumnya benar-benar meminta beragam bentuk jaminan, baik dari mudharib sendiri maupun dari pihak ketiga. Tetapi, mereka menegaskan bahwa jaminan tidak dibuat untuk memastikan kembalinya modal melainkan untuk memastikan bahwa kinerja mudharib sesuai dengan syarat-syarat

${ }^{3}$ Phillipus M. Hadjon, Perlindungan Hukum Bagi Rakyat Indonesia, Surabaya: Bina Ilmu, 1987, hlm.

${ }^{4}$ Sri Nurhayati dan Wasilah, Akuntansi Syariah di Indonesia, Cetakan Pertama, Jakarta: Salemba Empat, 2008, hlm. 112.

5 Muhammad, Manajemen Pembiayaan Mudharabah di Bank Syariah: Strategi Memaksimalkan Return dan Meminimalkan Risiko Pembiayaan di Bank Syariah sebagai Akibat Masalah Agency, (Jakarta: Rajawali, 2008), hlm. 41-42. 
akad $^{6}$, bukan bertujuan mengembalikan modal bank atau sebagai ganti rugi setiap kerugian atas kegagalan usaha mudharib secara mutlak. Oleh karena itu, jaminan hanya dapat dicairkan apabila pengelola dana terbukti melakukan pelanggaran, kelalaian, atau menyalahi kesepakatan yang telah ditentukan. ${ }^{7}$

Untuk meyakinkan bahwa agunan yang diberikan akan mampu menjamin pengembalian pembiayaan maka agunan yang diserahkan oleh debitur harus dilakukan pengikatan. Dan, sebagai tindak lanjut dari pemberian agunan tersebut, khususnya hak atas tanah, dituangkan ke dalam bentuk Akta Pemberian Hak Tanggungan (APHT), sebagai tersebut dan diatur Undang-Undang Nomor 4 Tahun 1996 tentang Hak Tanggungan atas Tanah beserta Benda-Benda yang Berkaitan Dengan Tanah (UU Hak Tanggungan : UUHT). ${ }^{8}$ APHT dibuat di muka dan di hadapan Pejabat Pembuat Akta Tanah (PPAT), sebagaimana dinyatakan dalam Pasal 10 ayat (2) UUHT.

Pejabat Pembuat Akta Tanah (PPAT), menurut pasal 1 Peraturan Pemerintah (PP) Nomor 37 Tahun 1998 tentang Peraturan Jabatan Pejabat Pembuat Akta Tanah yang telah diubah dengan PP Nomor 24 Tahun 2016, adalah pejabat umum yang diberi kewenangan untuk membuat akta-akta autentik mengenai perbuatan hukum tertentu mengenai Hak Atas Tanah atau Hak Milik Atas Satuan Rumah Susun. Hak tanggungan adalah hak jaminan atas tanah untuk pelunasan utang tertentu yang memberikan kedudukan diutamakan kepada kreditur tertentu terhadap kreditur-kreditur lain. ${ }^{9}$ APHT adalah akta PPAT yang berisi Pemberian Hak Tanggungan kepada kreditur tertentu sebagai jaminan untuk pelunasan piutangnya. APHT adalah perjanjian accessoir atau tambahan, yang merupakan perjanjian pokoknya adalah perjanjian utang atau perjanjian lain yang menimbulkan utang piutang. ${ }^{10}$

Dalam UUHT dan dalam blanko APHT selalu yang disebut sebagai perjanjian pokok adalah Perjanjian Utang. Oleh karena itu, bila perjanjian pokoknya bukan Perjanjian Utang maka APHT tidak dapat dibuat untuk menjadi jaminannya. Dalam praktik sehari-hari, ada beberapa perjanjian yang dibuat oleh Lembaga Keuangan yang harus dikaji lebih mendalam

6 Azharuddin Lathif, "Penerapan Hukum Jaminan dalam Pembiayaan di Perbankan Syari'ah" dalam https://www.academia.edu/6497716pdf, Akses 22 Mei 2016.

${ }^{7}$ Sri Nurhayati dan Wasilah, Akuntansi Syariah..., op.cit., hlm. 113.

${ }^{8}$ Habib Adjie dan Muhammad Hafidh, Akta Perbankan Syariah yang Selaras Pasal 38 UUJN-P, Edisi Revisi, Cetakan Pertama, (Semarang: Pustaka Zaman, 2014), hlm. 70.

${ }^{9}$ Adrian Sutedi, Hukum Hak Tanggungan, Cetakan Kedua, Jakarta: Sinar Grafika, 2012, hlm. 6.

${ }^{10}$ Mustofa, Tuntunan Pembuatan Akta-Akta PPAT, Cetakan Ketiga, Edisi Revisi, Yogyakarta: Karya Media, 2014, hlm. 269. 
apakah perjanjian tersebut termasuk perjanjian utang atau bukan. Perjanjian-perjanjian tersebut adalah Perjanjian Pasangan Usaha yang diberikan oleh Perusahaan Modal Ventura dan Perjanjian Pembiayaan yang diberikan oleh Bank dan Lembaga Keuangan Syariah. Bila setelah dikaji ternyata tidak termasuk perjanjian utang maka sebaiknya PPAT tidak membuatkan APHT sebagai bentuk penjaminannya karena dapat berakibat dimintakan pembatalan atau dapat juga menjadi batal demi hukum APHT nya. ${ }^{11}$

Menurut Sutan Remy Sjahdeini, akad mudharabah sama sekali bukan merupakan perjanjian utang piutang melainkan perjanjian kerjasama mengenai usaha bersama dengan para pihak. ${ }^{12}$ Berbeda dengan perjanjian kredit yang pada hakikatnya merupakan perjanjian utang-piutang antara kreditur dengan debitur. Dalam praktik perbankan, perjanjian kredit adalah suatu perjanjian di mana kreditur (bank) meminjamkan sejumlah uang kepada debitur dengan syarat-syarat dan ketentuan-ketentuan yang ditetapkan para pihak antara lain bahwa debitur berkewajiban melunasi utangnya setelah jangka waktu tertentu ditambah bunga provisi, denda dan biaya-biaya lain yang telah ditentukan. ${ }^{13}$

Jadi, dengan adanya perbedaan prinsip antara akad mudharabah dan perjanjian kredit tersebut maka APHT tidak dapat digunakan untuk pengikatan jaminan berupa hak atas tanah pada akad mudharabah. Meskipun telah ada UU Nomor 21 Tahun 2008 tentang Perbankan Syariah yang juga memerlukan barang atau benda jaminan tambahan tetapi ternyata dalam penjaminan tersebut masih menggunakan UUHT yang tidak syariah dan APHTnya tidak syariah juga. ${ }^{14}$

Konsep pengikatan jaminan berupa hak atas tanah menurut Hukum Positif di Indonesia dan Hukum Islam secara prinsip jelas berbeda dalam hal sumber atau dasar hukumnya. Namun, perbankan syariah masih menggunakan Hak Tanggungan sebagai pengikatan jaminan terhadap hak atas tanah. Hal ini menimbulkan permasalahan karena penerapan lembaga jaminan hak tanggungan adalah berdasarkan hukum positif Indonesia

${ }^{11}$ Ibid. hlm. 271-272.

12 Sutan Remy Sjahdeini, Perbankan Islam dan Kedudukannya dalam Tata Hukum Perbankan Indonesia, Cetakan Pertama, Jakarta: Pustaka Utama Grafiti, 1999, hlm. 34.

${ }^{13}$ Prihati Yuniarlin dan Dewi Nurul Musjtari, Hukum Jaminan dalam Praktik Perbankan Syariah Cetakan Pertama, Yogyakarta: Lab Hukum Fakultas Hukum Universitas Muhammadiyah Yogyakarta, 2009, hlm. 88-89.

${ }^{14}$ Habib Adjie dan Muhammad Hafidh, Akta ... op. cit., hlm. 71. 
sedangkan setiap kegiatan perbankan syariah harus berdasarkan ketentuan atau prinsip syariah. $^{15}$

\section{Rumusan Masalah}

Pertama, bagaimana konsep pengikatan jaminan terhadap hak atas tanah menurut Peraturan Perundang-Undangan di Indonesia dan Hukum Islam? Kedua, bagaimana peran dan tanggung jawab Pejabat Pembuat Akta Tanah (PPAT) terkait dengan Akta Pemberian Hak Tanggungan (APHT) dalam akad Mudharabah pada Bank Syariah?

\section{Tujuan Penelitian}

Pertama, untuk mengetahui bagaimana konsep pengikatan jaminan terhadap hak atas tanah menurut Peraturan Perundang-Undangan di Indonesia dan Hukum Islam sehingga dapat dirumuskan bagaimana seharusnya konsep pengikatan jaminan terhadap hak atas tanah yang sesuai untuk perbankan syariah berdasarkan prinsip syariah atau hukum Islam.

Kedua, untuk mengetahui bagaimana peran dan tanggung jawab PPAT terkait dengan APHT dalam akad Mudharabah pada Bank Syariah sehingga dapat ditentukan bagaimana pertanggungjawaban PPAT terkait dengan APHT dalam akad Mudharabah pada Bank Syariah lalu disesuaikan dengan konsep pengikatan jaminan terhadap hak atas tanah yang sesuai untuk perbankan syariah berdasarkan prinsip syariah atau hukum Islam, guna menentukan akta apa yang seharusnya dapat dibuat oleh PPAT sebagai pengikatan jaminan terhadap hak atas tanah yang sesuai untuk perbankan syariah.

\section{Metode Penelitian}

Metode yang digunakan dalam penelitian ini adalah yuridis normatif dan bersifat deskriptif-kualitatif dengan objek penelitiannya adalah UU Nomor 4 Tahun 1996, UU Nomor 21 Tahun 2008, Fatwa-Fatwa DSN-MUI, Kitab Undang-Undang Hukum Perdata, PP Nomor 37 tahun 1998 yang telah diubah dengan PP Nomor 24 Tahun 2016 dan PERKABAN Nomor 1 Tahun 2006 yang telah diubah dengan PERKABAN Nomor 23 Tahun 2009.

\footnotetext{
15 Dalam pasal 1 angka 12 Undang-Undang Republik Indonesia Nomor 21 Tahun 2008 tentang Perbankan Syariah menjelaskan bahwa "Prinsip Syariah adalah prinsip hukum Islam dalam kegiatan perbankan berdasarkan fatwa yang dikeluarkan oleh lembaga yang memiliki kewenangan dalam penetapan fatwa di bidang syariah" dan pasal 2 menyatakan bahwa "Perbankan Syariah dalam melakukan kegiatan usahanya berasaskan Prinsip Syariah, demokrasi ekonomi, dan prinsip kehati-hatian".
} 
Dalam penelitian ini akan digunakan bahan hukum primer, sekunder dan tersier. Bahan hukum primer seperti Kitab Undang-Undang Hukum Perdata (KUHPerdata), UU Nomor 7 Tahun 1992 yang telah diubah dengan UU Nomor 10 Tahun 1998 tentang Perbankan, UU Nomor 4 Tahun 1996 tentang Hak Tanggungan atas Tanah beserta BendaBenda yang Berkaitan dengan Tanah, UU Nomor 21 Tahun 2008 Tentang Perbankan Syariah, PP Nomor 37 tahun 1998 tentang Peraturan Jabatan Pejabat Pembuat Akta Tanah, Peraturan Bank Indonesia (PBI) Nomor 7/46/PBI/2005 tentang Akad Penghimpunan dan Penyaluran Dana bagi Bank yang Melaksanakan Kegiatan Usaha Berdasarkan Prinsip Syariah, Fatwa Dewan Syari'ah Nasional Majelis Ulama Indonesia (Fatwa DSN-MUI) Nomor 07/DSN-MUI/IV/2000 tentang Pembiayaan Mudharabah (Qiradh), Fatwa DSNMUI Nomor 74/DSN-MUI/I/2009 tentang Penjaminan Syariah, Fatwa DSN-MUI Nomor 25/DSN-MUI/III/2002 tentang Rahn, Fatwa DSN-MUI Nomor 68/DSN-MUI/III/2008 tentang Rahn Tasjily dan Fatwa DSN-MUI Nomor 92/DSN-MUI/IV/2014 tentang Pembiayaan yang Disertai Rahn (At-Tamwil Al-Mautsuq Bi Al-Rahn). Bahan hukum sekunder terutama adalah buku-buku yang terkait dengan konsep pengikatan jaminan terhadap hak atas tanah menurut Peraturan Perundang-Undangan di Indonesia dan Hukum Islam, dan juga buku-buku yang berkaitan dengan peran dan tanggung jawab PPAT terkait dengan APHT dalam akad Mudharabah pada Bank Syariah. Bahan hukum tersier dalam penelitian ini yaitu: Kamus Besar Bahasa Indonesia (KBBI) dan Kamus Hukum.

Penelitian dengan metode studi kepustakaan ini dilakukan oleh penulis melalui penelusuran terhadap dokumen-dokumen atau himpunan peraturan perundang-undangan serta menggunakan media internet untuk mendapatkan dan mengumpulkan data yang dibutuhkan. Selanjutnya data yang terkumpul akan ditelaah, dikaji serta dibahas untuk dilakukan perbandingan antar objek yang diteliti sehingga dapat ditarik kesimpulan darinya. Pada akhirnya, hasil penelitian tersebut akan disajikan secara deskriptif kualitatif.

Analisis deskriptif kualitatif dalam penelitian ini yaitu bahan hukum yang diperoleh dari penelitian tentang konsep pengikatan jaminan terhadap hak atas tanah menurut hukum positif Indonesia dan hukum Islam, dan juga peran dan tanggung jawab PPAT terkait dengan APHT dalam akad Mudharabah pada Bank Syariah lalu dituliskan secara mendalam dan dianalisis sesuai dengan peraturan yang berlaku. Penelitian ini dilakukan untuk menemukan bagaimana konsep pengikatan jaminan terhadap hak atas tanah yang sesuai untuk perbankan syariah berdasarkan prinsip syariah atau hukum Islam dan bagaimana peran dan tanggung jawab PPAT terkait dengan APHT dalam akad Mudharabah pada Bank Syariah.

\section{Hasil Penelitian dan Pembahasan}




\section{Konsep Pengikatan Jaminan Terhadap Hak atas Tanah Menurut Peraturan Perundang-Undangan di Indonesia}

Keberadaan jaminan kredit (collateral) merupakan persyaratan guna memperkecil risiko bank dalam menyalurkan kredit. ${ }^{16}$ Dalam hal menjamin pengembalian kredit yang diberikan bank maka terhadap jaminan atau agunan yang diserahkan oleh debiturnya harus dilakukan pengikatan. ${ }^{17}$ Dalam hal pengikatan jaminan terhadap hak atas tanah, dengan mulai berlakunya UUHT pada 9 April 1996, Hak Tanggungan merupakan satu-satunya lembaga hak jaminan atas tanah dalam Hukum Tanah Nasional yang tertulis. ${ }^{18}$

Hak tanggungan adalah hak jaminan atas tanah untuk pelunasan utang tertentu yang memberikan kedudukan diutamakan kepada kreditur tertentu terhadap kreditur-kreditur lain. ${ }^{19}$ Sebelum berlakunya UUHT maka peraturan perundang-undangan yang mengatur tentang pembebanan hak atas tanah adalah Bab 21 Buku II KUH Perdata, yang berkaitan dengan hipotek dan Credietverband dalam Staatsblad 1908-542 sebagaimana telah diubah dengan Staatsblad 1937-190. Kedua ketentuan tersebut sudah tidak berlaku karena tidak sesuai lagi dengan kebutuhan kegiatan perkreditan di Indonesia karena pada undang-undang lama yang dapat dijadikan objek hipotek dan credietverband hanyalah hak milik, hak guna usaha, dan hak guna bangunan, sedangkan pada UUHT, yang menjadi objek hak tanggungan tidak hanya ketiga hak atas tanah tersebut tetapi ditambah dengan hak pakai atas tanah dan hak atas tanah berikut bangunan, tanaman, dan hasil karya yang telah ada atau akan ada merupakan satu kesatuan dengan tanah tersebut dan merupakan hak milik pemegang hak atas tanah yang pembebanannya dengan tegas dan dinyatakan di dalam akta pemberian hak tanggungan atas tanah yang bersangkutan. ${ }^{20}$

Subjek hak tanggungan diatur dalam Pasal 8 sampai dengan Pasal 9 UUHT. Dalam kedua pasal itu ditentukan bahwa yang dapat menjadi subjek hukum dalam pembebanan hak tanggungan adalah pemberi hak tanggungan dan pemegang hak tanggungan. Pemberi hak tanggungan dapat perorangan atau badan hukum, yang mempunyai kewenangan untuk melakukan perbuatan hukum terhadap objek hak tanggungan. Pemegang hak tanggungan

${ }^{16}$ Budi Untung, Kredit Perbankan di Indonesia, Edisi Kedua, Yogyakarta: Andi, 2011, hlm. 60.

${ }^{17}$ Ibid., hlm. 66.

${ }^{18}$ Boedi Harsono, Hukum Agraria Indonesia, Sejarah Pembentukan Undang-Undang Pokok Agraria, Isi dan Pelaksanaanya, Jilid 1 Hukum Tanah Nasional, (Jakarta: Djambatan, 2008), hlm. 416.

${ }^{19}$ Adrian Sutedi, loc. cit.

20 Salim HS., Perkembangan Hukum Jaminan di Indonesia, Edisi Pertama, Cetakan Pertama, (Jakarta: Raja Grafindo Persada, 2004), hlm. 95. 
terdiri dari perorangan atau badan hukum, yang berkedudukan sebagai pihak berpiutang. Biasanya dalam praktik, pemberi hak tanggungan disebut dengan debitur, yaitu yang meminjamkan uang di lembaga perbankan sedangkan penerima hak tanggungan disebut dengan istilah kreditur, yaitu orang atau badan hukum yang berkedudukan sebagai pihak berpiutang. ${ }^{21}$

\section{Konsep Pengikatan Jaminan Terhadap Hak Atas Tanah Menurut Hukum Islam}

Konsep pengikatan jaminan berupa hak atas tanah menurut hukum Islam yang mirip konstruksi hukumnya seperti Hak Tanggungan adalah Rahn. Rahn adalah menahan salah satu harta milik si peminjam atau nasabah (rahin) sebagai jaminan (marhun) atas pinjaman (marhun bih) yang diterimanya. Barang yang ditahan tersebut memiliki nilai ekonomis. Dengan demikian, pihak yang menahan memperoleh jaminan untuk dapat mengambil kembali seluruh atau sebagian piutangnya. ${ }^{22}$ Menurut A. A. Basyir, rahn adalah perjanjian menahan sesuatu barang sebagai tanggungan utang atau menjadikan sesuatu benda bernilai menurut pandangan syara' sebagai tanggungan marhun bih sehingga dengan adanya tanggungan utang itu seluruh atau sebagian utang dapat diterima. ${ }^{23}$

Menurut Muhammad, ${ }^{24}$ rahn termasuk dalam kategori akad pelengkap dalam Produk Operasional Bank Syariah di Indonesia yang tujuannya adalah untuk memberikan jaminan pembayaran kembali kepada bank dalam memberikan pembiayaan. Barang yang digadaikan wajib memenuhi kriteria.

1. Milik nasabah sendiri,

2. Jelas ukuran, sifat dan nilainya ditentukan berdasarkan nilai riil pasar,

3. Dapat dikuasai namun tidak boleh dimanfaatkan oleh bank.

Sasli Rais menegaskan bahwa dalam hukum perdata, hak gadai hanya berlaku pada benda bergerak sedangkan dalam hukum Islam, rahn berlaku pada seluruh benda atau harta, baik harta yang bergerak maupun yang tidak bergerak. ${ }^{25}$ Menurut Dewan Syariah Nasional, Rahn yaitu menahan barang sebagai jaminan atas utang. Sedangkan menurut Bank

${ }^{21}$ Ibid., hlm. 103-104.

${ }^{22}$ Muhammad Syafi'i Antonio, Bank ..., op.,cit., hlm. 128.

${ }^{23}$ A. A. Basyir, Hukum Islam tentang Riba, Utang-Piutang Gadai, dikutip dari Sasli Rais, Pegadaian Syariah: Konsep dan Sistem Operasional, Suatu Kajian Kontemporer, (Jakarta: UI-Press, 2005), hlm. 38.

${ }^{24}$ Muhammad, Manajemen Bank ... op.cit., hlm. 101.

${ }^{25}$ Sasli Rais, Pegadaian ... op.cit., hlm 47. 
Indonesia, Rahn adalah akad penyerahan barang atau harta (marhun) dari nasabah (rahin) kepada Bank (murtahin) sebagai jaminan sebagian atau seluruh utang. ${ }^{26}$

Landasan Syariah Rahn ${ }^{27}$ terdapat dalam Al-Qur'an surat Al-Baqarah ayat 283 yang berbunyi:

"Dan apabila kamu dalam perjalanan sedang kamu tidak memperoleh seorang juru tulis maka hendaklah ada barang tanggungan yang dipegang (oleh yang berpiutang) ..."

Ayat tersebut secara eksplisit menyebutkan "barang tanggungan yang dipegang (oleh yang berpiutang)". Dalam dunia finansial, barang tanggungan biasa dikenal sebagai jaminan (collateral) atau objek pegadaian.

Selain itu, landasan syariah rahn terdapat juga dalam Al-Hadis yaitu

“Aisyah r.a. berkata, bahwa Rasulullah membeli makanan dari seorang Yahudi, dan menjaminkan kepadanya baju besi." (HR Bukhari no. 1926, kitab al-Buyu, dan Muslim)

Anas r.a. berkata,

"Rasulullah menggadaikan baju besinya kepada seorang Yahudi di Madinah dan mengambil darinya gandum untuk keluarga beliau." (HR Bukhari no. 1927, kitab alBuyu, Ahmad, Nasa'i dan Ibnu Majah)

Dari uraian mengenai rahn tersebut, berarti dalam hukum Islam memiliki lembaga jaminan tersendiri yang dapat digunakan pada benda bergerak ataupun benda tidak bergerak. Fatwa DSN-MUI yang mengatur tentang rahn adalah Fatwa Dewan Syariah Nasional Nomor 25/DSN-MUI/III/2002. Berdasarkan fatwa tersebut bahwa pinjaman dengan menggadaikan barang sebagai jaminan utang dalam bentuk Rahn diperbolehkan. ${ }^{28}$ Dewan Syariah Nasional Majelis Ulama Indonesia (DSN-MUI) bahkan telah memberikan fatwa yang khusus mengatur tentang rahn yang dapat digunakan pada benda yang tidak bergerak seperti tanah yaitu Fatwa Dewan Syari'ah Nasional Nomor 68/DSN-MUI/III/2008 tentang

\footnotetext{
${ }^{26}$ Faturrahman Djamil, Penyelesaian Pembiayaan Bermasalah di Bank Syariah, Cetakan Pertama, (Jakarta: Sinar Grafika, 2012), hlm. 45.

${ }^{27}$ Muhammad Syafi'i Antonio, Bank ..., op.,cit., hlm. 128-129.

${ }^{28}$ Tim Penyunting Erlangga, Himpunan Fatwa Keuangan Syariah, Dewan Syariah Nasional MUI, (Jakarta: Erlangga, 2014), hlm. 738.
} 
Rahn Tasjily. Pada bagian Pertama tentang Ketentuan Umum dalam fatwa tersebut dinyatakan bahwa: ${ }^{29}$

"Rahn Tasjîly - disebut juga dengan Rahn Ta'mîn̂̂, Rahn Rasmî atau Rahn $\underline{H} u k m \hat{\imath}$ adalah jaminan dalam bentuk barang atas utang, dengan kesepakatan bahwa yang diserahkan kepada penerima jaminan (murtahin) hanya bukti sah kepemilikannya sedangkan fisik barang jaminan tersebut (marhûn) tetap berada dalam penguasaan dan pemanfaatan pemberi jaminan (Râhin)."

Berkaitan dengan akad mudharabah yang menjadi pembahasan dalam penelitian ini, berlaku secara khusus Fatwa DSN-MUI Nomor 92/DSN-MUI/IV/2014 tentang Pembiayaan yang Disertai Rahn (At-Tamwil Al-Mautsuq Bi Al-Rahn). Ketentuan dalam fatwa ini berlaku untuk semua bentuk pembiayaan/penyaluran dana Lembaga Keuangan Syariah (LKS) yang mana boleh dijamin dengan agunan (Rahn). ${ }^{30}$

Namun, dalam praktik perbankan syariah di Indonesia, hukum formal yang mengatur hubungan hukum antara bank syariah dengan nasabah (pembiayaan dan penyimpan dana) diatur berdasarkan KUHPerdata, termasuk di dalamnya mengenai jaminan $^{31}$ (belum mengacu pada fatwa-fatwa tersebut di atas). Sebagaimana yang dinyatakan Faturrahman Djamil bahwa mengingat pengikatan jaminan bagi bank syariah sampai saat ini belum ada pengaturan secara khusus maka pelaksanaan pengikatan jaminan yang dilakukan oleh bank syariah adalah dengan memberlakukan peraturan perundangundangan konvensional yang ada tentang lembaga jaminan. ${ }^{32}$

Keberadaan Rahn dan Rahn Tasjîly berdasarkan Fatwa DSN-MUI, seharusnya dapat menjadi sumber hukum yang merupakan pengaturan secara khusus dalam pengikatan jaminan pada perbankan syariah, terutama pengikatan jaminan terhadap hak atas tanah. Perbankan syariah memerlukan suatu peraturan perundang-undangan yang secara lengkap dan teknis mengatur pengikatan jaminan terhadap hak atas tanah, sebagaimana keberadaan lembaga jaminan Hak Tanggungan pada perbankan konvensional. Oleh karena itu, konsep pengikatan jaminan dalam Rahn dan Rahn Tasjîly diharapkan dapat segera diatur dalam suatu Undang-Undang agar dapat menjadi dasar hukum bagi lembaga jaminan terhadap hak atas tanah pada perbankan syariah. Juli 2016.

${ }^{29}$ Ibid., hlm. 744.

${ }^{30}$ http://www.khafidzt.ga/2015/03/92dsn-muiiv2014-pembiayaan-yang-disertai-rahn.pdf, Akses 28

${ }^{31}$ Prihati Yuniarlin dan Dewi Nurul Musjtari, Hukum ...op. cit., hlm. 179.

${ }^{32}$ Faturrahman Djamil, Penyelesaian ... op. cit., hlm. 41. 
Selain itu, ada aspek hukum lain yang perlu diperhatikan dalam rancangan pembentukan Undang-Undang tersebut yaitu PP Nomor 37 Tahun 1998 yang telah diubah dengan PP Nomor 24 Tahun 2016. Dalam Pasal 1 PP tersebut dinyatakan bahwa:

"Pejabat Pembuat Akta Tanah adalah pejabat umum yang diberi kewenangan untuk membuat akta-akta autentik mengenai perbuatan hukum tertentu mengenai hak atas tanah atau Hak Milik Atas Satuan Rumah Susun."

maka pengikatan jaminan terhadap hak atas tanah secara syariah seharusnya juga dapat dilakukan oleh PPAT agar autentisitas terhadap akta pengikatan jaminannya dapat terpenuhi secara sempurna karena berdasarkan ketentuan pasal 1 PP tersebut di atas bahwa akta PPAT adalah akta autentik.

Dengan lahirnya Undang-Undang yang khusus mengatur tentang pengikatan jaminan terhadap hak atas tanah untuk perbankan syariah maka unsur kesyariahan dalam setiap akad perbankan syariah dapat terwujud dan terpenuhi secara sempurna sehingga tidak perlu lagi menggunakan APHT sebagai pengikatan jaminan terhadap hak atas tanah yang digunakan perbankan konvensional, khususnya akad mudharabah.

\section{Peran Dan Tanggung Jawab Pejabat Pembuat Akta Tanah (PPAT) Terkait Dengan Akta Pemberian Hak Tanggungan (APHT) Dalam Akad Mudharabah Pada Bank Syariah}

Dalam praktik perbankan syariah, pembiayaan Mudharabah biasanya diikuti dengan proses pembebanan hak tanggungan terhadap hak atas tanah yang dijaminkan oleh nasabah kepada bank syariah yang kemudian dituangkan ke dalam bentuk Akta Pemberian Hak Tanggungan (APHT), sebagai tersebut dan diatur UU Nomor 4 Tahun 1996 (UUHT) ${ }^{33}$ yang dibuat di muka dan di hadapan Pejabat Pembuat Akta Tanah (PPAT).

Pejabat Pembuat Akta Tanah (PPAT), menurut pasal 1 PP Nomor 37 Tahun 1998 adalah pejabat umum yang diberi kewenangan untuk membuat akta-akta autentik mengenai perbuatan hukum tertentu mengenai hak atas tanah atau Hak Milik Atas Satuan Rumah Susun.

Dalam Pasal 53 PERKABAN Nomor 1 Tahun 2006, dinyatakan bahwa:

1. Akta PPAT dibuat dengan mengisi blanko akta yang tersedia secara lengkap sesuai petunjuk pengisiannya.

\footnotetext{
${ }^{33}$ Habib Adjie dan Muhammad Hafidh, loc. cit.
} 


\section{$270 \mathrm{LEx}$ Renaissance No. 2 VOL. 1 JULI 2016: 258 - 276}

2. Pengisian blanko akta dalam rangka pembuatan akta PPAT sebagaimana dimaksud pada ayat (1) harus dilakukan sesuai dengan kejadian, status dan data yang benar serta didukung dengan dokumen sesuai peraturan perundang-undangan.

Berdasarkan isi pasal tersebut, memang peran PPAT hanya mengisi blanko akta yang telah dibuat dan diterbitkan oleh Badan Pertanahan Nasional Republik Indonesia (BPN RI) dan selama ini telah menjadi permakluman umum bahwa akad Mudharabah dapat diikuti dengan APHT sebagai akta penjaminannya. ${ }^{34}$

Dalam pembuatan akta-akta autentik mengenai perbuatan hukum tertentu mengenai hak atas tanah atau Hak Milik Atas Satuan Rumah Susun, PPAT dituntut kecermatan, ketelitian dan kehati-hatiannya walaupun hanya mengisi blanko yang telah dibuat dan diterbitkan oleh Badan Pertanahan Nasional Republik Indonesia (BPN RI) karena jika terjadi suatu kesalahan atau kekeliruan dalam pembuatan akta-akta PPAT tersebut dapat berakibat kebatalan pada akta-akta tersebut.

Dalam hal pembuatan APHT pada akad Mudharabah oleh PPAT maka APHT tersebut dapat menjadi batal demi hukum karena tidak terpenuhinya syarat yang diharuskan oleh Undang-Undang, sebagaimana dijelaskan pada bagian Penjelasan Umum UUHT angka (8) bahwa:

"Oleh karena Hak Tanggungan menurut sifatnya merupakan ikutan atau accessoir pada suatu piutang tertentu, yang didasarkan pada suatu perjanjian utang-piutang atau perjanjian lain, maka kelahiran dan keberadaannya ditentukan oleh adanya piutang yang dijamin pelunasannya."

Hal ini tentunya berakibat hukum kepada pihak bank menjadi tidak dapat mengeksekusi jaminan berupa hak atas tanah apabila debitur, dalam hal ini mudharib, tidak dapat memenuhi prestasi atau kewajibannya sesuai isi kesepakatan dalam akad atau diistilahkan dalam hukum perikatan dengan wanprestasi. Jika ini terus dilakukan maka tentu akan merugikan bagi pihak perbankan syariah apalagi jika debitur lebih mengetahui dan memahami persoalan ini.

Dalam PERKABAN BPN RI Nomor 1 tahun 2006 tentang Ketentuan Pelaksanaan PP Nomor 37 Tahun 1998 tentang Peraturan Jabatan PPAT yang telah diubah dengan PERKABAN Nomor 23 Tahun 2009 dan PP Nomor 37 tahun 1998 tentang Peraturan Jabatan Pejabat Pembuat Akta Tanah yang telah diubah dengan PP Nomor 24 Tahun 2016, tidak dicantumkan secara khusus mengenai sanksi yang dapat dikenakan kepada PPAT yang

\footnotetext{
${ }^{34}$ Faturrahman Djamil, Penyelesaian ... op.cit., hlm. 41.
} 
melakukan pelanggaran atau kelalaian dalam melaksanakan tugas jabatannya tetapi pada bagian Penjelasan Umum UUHT angka 11 ditegaskan mengenai adanya sanksi administratif sebagai berikut:

"Untuk menjamin kepastian hukum serta memberikan perlindungan kepada pihakpihak yang berkepentingan, dalam Undang-Undang ini diatur sanksi administratif yang dikenakan kepada para pelaksana yang bersangkutan, terhadap pelanggaran atau kelalaian dalam memenuhi berbagai ketentuan pelaksanaan tugasnya masingmasing. Selain dikenakan sanksi administratif tersebut di atas, apabila memenuhi syarat yang diperlukan, yang bersangkutan masih dapat digugat secara perdata dan/atau dituntut pidana."

Sanksi Administratif yang dikenakan kepada PPAT karena kelalaian dalam memenuhi berbagai ketentuan pelaksanaan tugasnya masing-masing, tercantum dalam Pasal 23 ayat (1) UUHT, yang berbunyi:

"Pejabat yang melanggar atau lalai dalam memenuhi ketentuan sebagaimana dimaksud dalam Pasal 11 ayat (1), Pasal 13 ayat (2), dan Pasal 15 ayat (1) Undangundang ini dan/atau peraturan pelaksanaannya dapat dikenai sanksi administratif, berupa:

a. teguran lisan;

b. teguran tertulis;

c. pemberhentian sementara dari jabatan;

d. pemberhentian dari jabatan."

PPAT yang telah membuatkan APHT pada akad Mudharabah pada bank syariah tentunya dapat dimintai pertanggungjawaban hukum karena telah mengakibatkan kerugian bagi pihak bank syariah. Berdasarkan teori pertanggungjawaban yang dikemukakan oleh Ridwan maka hal ini termasuk kepada konsep liability yang menunjuk pada pertanggungjawaban hukum yaitu tanggung gugat akibat kesalahan yang dilakukan oleh subyek hukum yaitu PPAT. ${ }^{35}$ Dan berdasarkan teori tanggung jawab dalam perbuatan melawan hukum (tort liability) oleh Abdulkadir Muhammad ${ }^{36}$ maka PPAT yang telah membuatkan APHT pada akad Mudharabah dapat dituntut tanggung jawabnya akibat perbuatan melawan hukum yang dilakukan karena kelalaian (negligence tort lilability), didasarkan pada konsep kesalahan (concept of fault) yang berkaitan dengan moral dan

35 Ridwan HR, Hukum Administrasi Negara, Edisi Revisi, Cetakan Kesebelas, (Jakarta: Raja Grafindo Persada, 2014), hlm. 318-321.

${ }^{36}$ Abdulkadir Muhammad, Hukum Perusahaan Indonesia, (Bandung: Citra Aditya Bakti, 2010), hlm. 503. 


\section{LEx Renaissance No. 2 VOL. 1 JULI 2016: 258 - 276}

hukum yang sudah bercampur baur (interminglend), di mana dalam praktik perbankan syariah telah terjadi percampuran penggunaan peraturan perundang-undangan (UUHT digunakan sebagai dasar hukum pengikatan jaminan dan di sisi lain, untuk perjanjian atau akad-akad pokoknya telah bersumber pada UU Perbankan Syariah dan Fatwa-Fatwa DSNMUI serta Peraturan Bank Indonesia, sehingga terjadi kekeliruan dan ketidakjelasan terhadap esensi dari perjanjian pokoknya).

PPAT yang telah membuatkan APHT pada akad Mudharabah bank syariah dapat dimintakan pertanggungjawaban secara perdata karena sebagaimana dijelaskan di atas bahwa perbuatan itu bertentangan dengan UUHT yang menjelaskan bahwa perjanjian pokok dari APHT haruslah perjanjian utang-piutang. Pertanggungjawaban dalam bidang perdata dapat dilihat secara yuridis formal yang diatur dalam Pasal 1365 dan 1366 KUHPerdata. Pasal 1365 KUHPerdata berbunyi: ${ }^{37}$

"Tiap perbuatan yang melanggar hukum dan membawa kerugian kepada orang lain, mewajibkan orang yang menimbulkan kerugian itu karena kesalahannya untuk menggantikan kerugian tersebut."

\section{Pasal 1366 KUHPerdata berbunyi: ${ }^{38}$}

"Setiap orang bertanggung jawab bukan hanya atas kerugian yang disebabkan perbuatan-perbuatan melainkan juga atas kerugian yang disebabkan kelalaian atau kesembronoannya."

Merujuk kepada penjelasan Pasal 1365 dan 1366 KUHPerdata di atas maka jelas PPAT yang telah membuatkan APHT pada akad Mudharabah bank syariah dapat dimintakan pertanggungjawaban secara perdata karena akibat kelalaiannya, pihak bank dapat mengalami kerugian yaitu pihak bank tidak dapat mengeksekusi jaminan berupa hak atas tanah apabila debitur atau mudharib, tidak dapat memenuhi prestasi atau wanprestasi.

Pembuatan APHT dalam akad Mudharabah Bank Syariah kepada PPAT, tentunya adalah atas dasar permintaan pihak bank itu sendiri dan memang selama ini telah menjadi permakluman umum bahwa akad Mudharabah dapat diikuti dengan APHT sebagai akta penjaminannya. Namun, seharusnya pihak perbankan syariah juga melakukan analisa kesyariahan yang mendalam secara fiqh mu'amalah terhadap setiap Produk Operasional Bank

\footnotetext{
37 Ahmadi Miru dan Sakka Pati, Hukum Perikatan Penjelasan Makna Pasal 1233 sampai 1456, (Jakarta: Rajawali Pers, 2008) hlm. 96.

38 Ibid., hlm. 98.
} 
Syariah supaya tidak menimbulkan permasalahan dan kerugian di kemudian hari pada Bank Syariah itu sendiri.

Dengan pesatnya pertumbuhan perbankan syariah di Indonesia maka diharapkan ke depannya, pemerintah dapat membuat suatu peraturan perundang-undangan yang khusus mengatur tentang pengikatan jaminan terhadap hak atas tanah untuk perbankan syariah sehingga unsur kesyariahan dalam setiap akad-akad perbankan syariah dapat terwujud dan terpenuhi secara sempurna dan tidak perlu lagi menggunakan APHT sebagai pengikatan jaminan terhadap hak atas tanah yang digunakan perbankan konvensional, khususnya pada akad mudharabah.

\section{Penutup}

Dari uraian di atas dapat diambil kesimpulan; Pertama, konsep pengikatan jaminan terhadap hak atas tanah dengan menggunakan Hak Tanggungan yang dituangkan ke dalam bentuk APHT tidak dapat digunakan pada perjanjian pokok berupa Akad Mudharabah. Karena, berdasarkan pejelasan umum pada UUHT bahwa Hak Tanggungan menurut sifatnya merupakan ikutan atau accessoir pada suatu piutang tertentu, yang didasarkan pada suatu perjanjian utangpiutang. Sementara Akad Mudharabah adalah akad kerjasama usaha antara bank sebagai pemilik dana (shahibul maal) dan nasabah sebagai pengelola dana (mudharib) untuk melakukan kegiatan usaha dengan nisbah pembagian hasil (keuntungan atau kerugian/profit and loss sharing) menurut kesepakatan kedua belah pihak.

Kedua, konsep pengikatan jaminan berupa hak atas tanah menurut hukum Islam yang mirip konstruksi hukumnya seperti Hak Tanggungan adalah Rahn. Fatwa DSN-MUI yang mengatur tentang rahn adalah Fatwa Dewan Syariah Nasional Nomor 25/DSNMUI/III/2002. Dewan Syariah Nasional Majelis Ulama Indonesia (DSN-MUI) dan ada pula fatwa yang khusus mengatur tentang rahn yang dapat digunakan pada benda yang tidak bergerak seperti tanah yaitu Fatwa Dewan Syari'ah Nasional Nomor 68/DSN-MUI/III/2008 tentang Rahn Tasjily. Berkaitan dengan akad mudharabah yang menjadi pembahasan dalam penelitian ini, berlaku secara khusus Fatwa DSN-MUI Nomor 92/DSN-MUI/IV/2014 tentang Pembiayaan yang Disertai Rahn (At-Tamwil Al-Mautsuq Bi Al-Rahn).

Ketiga, peran PPAT hanya mengisi blanko akta yang telah dibuat dan diterbitkan oleh Badan Pertanahan Nasional Republik Indonesia (BPN RI) dan selama ini telah menjadi permakluman umum bahwa akad Mudharabah dapat diikuti dengan APHT sebagai akta penjaminannya. PPAT yang telah membuatkan APHT pada akad Mudharabah pada bank syariah tentunya dapat dimintai pertanggungjawaban hukum secara perdata atau pidana 
karena telah mengakibatkan kerugian bagi pihak bank syariah, sebagaimana dijelaskan pada bagian Penjelasan Umum UUHT angka 11 ditegaskan mengenai adanya sanksi administratif. Dalam hal pembuatan APHT dalam akad Mudharabah Bank Syariah kepada PPAT, tentunya adalah atas dasar permintaan pihak bank itu sendiri dan memang selama ini telah menjadi permakluman umum bahwa akad Mudharabah dapat diikuti dengan APHT sebagai akta penjaminannya. Maka, kesalahan dan kelalaian tersebut tidak dapat mutlak dipertanggungjawabkan kepada PPAT saja.

Adapun saran yang ingin peneliti sampaikan adalah; Pertama, seharusnya pihak perbankan syariah melakukan analisa kesyariahan yang mendalam secara fiqh mu'amalah terhadap setiap Produk Operasional Bank Syariah yang akan dikeluarkannya supaya tidak menimbulkan permasalahan dan kerugian di kemudian hari pada Bank Syariah itu sendiri.

Kedua, keberadaan Rahn dan Rahn Tasjîly berdasarkan Fatwa Dewan Syari'ah Nasional Majelis Ulama Indonesia, seharusnya dapat menjadi sumber hukum yang merupakan pengaturan secara khusus dalam pengikatan jaminan pada perbankan syariah, terutama pengikatan jaminan terhadap hak atas tanah. Karena, perbankan syariah memerlukan suatu peraturan perundang-undangan yang secara lengkap dan teknis mengatur pengikatan jaminan terhadap hak atas tanah, sebagaimana keberadaan lembaga jaminan Hak Tanggungan pada perbankan konvensional. Oleh karena itu, konsep pengikatan jaminan dalam Rahn dan Rahn Tasjîly diharapkan dapat segera diatur dalam suatu Undang-Undang agar dapat menjadi dasar hukum bagi lembaga jaminan terhadap hak atas tanah pada perbankan syariah. Dan, unsur kesyariahan dalam setiap akad-akad perbankan syariah dapat terwujud dan terpenuhi secara sempurna dan tidak perlu lagi menggunakan APHT sebagai pengikatan jaminan terhadap hak atas tanah yang digunakan perbankan konvensional, khususnya pada akad mudharabah.

Ketiga, karena berdasarkan PP Nomor 37 tahun 1998 yang telah diubah dengan PP Nomor 24 Tahun 2016, yang berwenang membuat akta terkait perbuatan hukum tertentu mengenai hak atas tanah atau Hak Milik Atas Satuan Rumah Susun adalah PPAT maka diharapkan akta Rahn sebagai akta pengikatan jaminan terhadap hak atas tanah untuk perbankan syariah juga menjadi kewenangan PPAT untuk membuatnya agar terpenuhi autentisitas akta tersebut, dan kewenangan itu ditetapkan melalui suatu peraturan perundang-undangan agar mendapat kepastian hukum. Hal ini sebagaimana akta Hibah yang telah menjadi kewenangan PPAT untuk membuatnya dan akta Hibah juga merupakan perjanjian yang bersumber pada Hukum Islam.

\section{Daftar Pustaka}


Abdulkadir Muhammad, Hukum Perusahaan Indonesia, Citra Aditya Bakti, Bandung, 2010.

Adrian Sutedi, Hukum Hak Tanggungan, Cetakan Kedua, Sinar Grafika, Jakarta, 2012.

Ahmadi Miru dan Sakka Pati, Hukum Perikatan Penjelasan Makna Pasal 1233 sampai 1456, Rajawali Pers, Jakarta, 2008.

Boedi Harsono, Hukum Agraria Indonesia, Sejarah Pembentukan Undang-Undang Pokok Agraria, Isi dan Pelaksanaanya, Jilid 1 Hukum Tanah Nasional, Djambatan, Jakarta, 2008.

Budi Untung, Kredit Perbankan di Indonesia, Edisi Kedua, Andi, Yogyakarta, 2011.

Faturrahman Djamil, Penyelesaian Pembiayaan Bermasalah di Bank Syariah, Cetakan Pertama, Sinar Grafika, Jakarta, 2012.

Habib Adjie dan Muhammad Hafidh, Akta Perbankan Syariah yang Selaras Pasal 38 UUJN-P, Edisi Revisi, Cetakan Pertama, Pustaka Zaman, Semarang, 2014.

Muhammad Syafi'i Antonio, Bank Syariah, Dari Teori Ke Praktik, Gema Insani Press bekerjasama dengan Tazkia Cendikia, Jakarta, 2001.

Muhammad, Manajemen Bank Syariah, Edisi Revisi, UPP AMP YKPN, Yogyakarta, 2005.

- Manajemen Pembiayaan Mudharabah di Bank Syariah: Strategi Memaksimalkan Return dan Meminimalkan Risiko Pembiayaan di Bank Syariah sebagai Akibat Masalah Agency, Rajawali, Jakarta, 2008.

Mustofa, Tuntunan Pembuatan Akta-Akta PPAT, Cetakan Ketiga, Edisi Revisi, Karya Media, Yogyakarta, 2014.

Phillipus M. Hadjon, Perlindungan Hukum Bagi Rakyat Indonesia, Bina Ilmu, Surabaya, 1987.

Prihati Yuniarlin dan Dewi Nurul Musjtari, Hukum Jaminan dalam Praktik Perbankan Syariah Cetakan Pertama, Lab Hukum Fakultas Hukum Universitas Muhammadiyah Yogyakarta, Yogyakarta, 2009.

Ridwan HR, Hukum Administrasi Negara, Edisi Revisi, Cetakan Kesebelas, Raja Grafindo Persada, Jakarta, 2014.

Salim HS., Perkembangan Hukum Jaminan di Indonesia, Edisi I, Cetakan I, Raja Grafindo Persada, Jakarta, 2004.

Sasli Rais, Pegadaian Syariah: Konsep dan Sistem Operasional, Suatu Kajian Kontemporer, UI-Press, Jakarta, 2005.

Sri Nurhayati dan Wasilah, Akuntansi Syariah di Indonesia, Cetakan Pertama, Salemba Empat, Jakarta, 2008.

Sutan Remy Sjahdeini, Perbankan Islam dan Kedudukannya dalam Tata Hukum Perbankan Indonesia, Cetakan Pertama, Pustaka Utama Grafiti, Jakarta, 1999.

Tim Penyunting Erlangga, Himpunan Fatwa Keuangan Syariah, Dewan Syariah Nasional MUI, Erlangga, Jakarta, 2014. 


\section{PERATURAN PERUNDANG-UNDANGAN}

Kitab Undang-Undang Hukum Perdata

Peraturan Pemerintah (PP) Nomor 37 Tahun 1998 yang telah diubah dengan PP Nomor 24 Tahun 2016 tentang Perubahan Atas Peraturan Pemerintah Nomor 37 Tahun 1998 tentang Peraturan Jabatan Pejabat Pembuat Akta Tanah

Peraturan Kepala Badan Pertanahan Nasional Republik Indonesia (PERKABAN) Nomor 1 Tahun 2006 yang telah diubah dengan PERKABAN Nomor 23 Tahun 2009 tentang Perubahan Atas PERKABAN Nomor 1 Tahun 2006 tentang Ketentuan Pelaksanaan PP Nomor 37 Tahun 1998 tentang Peraturan Jabatan PPAT

Peraturan Bank Indonesia (PBI) Nomor 7/46/PBI/2005 tentang Akad Penghimpunan dan Penyaluran Dana bagi Bank yang Melaksanakan Kegiatan Usaha Berdasarkan Prinsip Syariah;

Undang-Undang Nomor 21 Tahun 2008 Tentang Perbankan Syariah.

Undang-Undang Nomor 4 Tahun 1996 tentang Hak Tanggungan atas Tanah beserta BendaBenda yang Berkaitan dengan Tanah.

Undang-Undang Nomor 7 Tahun 1992 jo. Undang-Undang Nomor 10 Tahun 1998 tentang Perbankan;

\section{INTERNET}

Azharuddin Lathif, Penerapan Hukum Jaminan Dalam Pembiayaan di Perbankan Syari'ah, dalam https://www.academia.edu/6497716pdf, Akses 22 Mei 2016.

Fatwa DSN-MUI Nomor 92/DSN-MUI/IV/2014 tentang Pembiayaan yang Disertai Rahn (At-Tamwil Al-Mautsuq Bi Al-Rahn), dalam http://www.khafidzt.ga/2015/03/92dsn-muiiv2014-pembiayaan-yang disertairahn.pdf, Akses 2 Juli 2016.

Muhammad Ananda Salahuddin Al Ayyubi Basmalah, "Analisis Yuridis Kedudukan Jaminan Hak Tanggungan dalam Perspektif Bisnis Syariah”, Tesis, Program Studi Hukum Bisnis Syariah UIN Sunan Kalijaga, Yogyakarta, 2014, dalam http://digilib.uinsuka.ac.id/15652/1/BAB\%20I,\%20V,\%20DAFTAR\%20PUSTAKA.pdf, Akses 23 Mei 2016. 